\title{
PERBAIKAN KUALITAS NIRA AREN MENGGUNAKAN BEBERAPA PENGAWET ALAMI
}

\author{
Ati Atul Quddus ${ }^{1}$, Hari Hariadi ${ }^{1}$ \\ ${ }^{1}$ Program Studi Ilmu dan Teknologi Pangan, Fakultas Pertanian, Universitas \\ Garut, Jl. Raya Samarang No.52A, Tarogong Kaler, Kabupaten Garut, Jawa Barat \\ 44151 \\ atiquddussyaiful@gmail.com, harihariadi@gmail.com
}

\begin{abstract}
Indonesia is one of the sugar producing countries in the world, but the domestic sugar industry is still unable to meet the needs of its own country. The condition of sugar self-sufficiency is pursued through the development of sugar cane and also through other sources of raw materials, one of which is from palm sugar. Palm juice quickly changes to acid because of the fermentation process, which is usually caused by late processing after tapping, or because of the uncleanness of the juice container. This study aims to observe the effect of giving natural preservatives in the form of hiris leaf powder, mangosteen peel powder, and palm sugar in maintaining the quality of palm juice done in several concentrations ( $b$ / $v)$. The research method used was an experimental method with a method. The first factor was 3 levels of natural preservative types (mangosteen peel powder, sliced leaves, and brown sugar), while factor II was 3 preservative concentration levels $(3 \%, 4.5 \%$, and $6 \%)$, and each treatment was repeated 3 times so that it was obtained 27 trial units. The test results showed that the lowest reducing sugar content in palm sugar using natural preservatives was found in the Hiris Leaf with an average of $31.192 \%$ and 4.5 treatment dose with an average of $34.683 \%$. While for the lowest moisture content found in palm sugar that uses natural preservatives of mangosteen peel with an average of $1.5983 \%$ and the best treatment dose is at dose 3 with an average of $1.1267 \%$
\end{abstract}

Keywords: hiris leaves, mangosteen peel, palm juice, natural preservatives

\section{PENDAHULUAN}

Indonesia merupakan salah satu negara produsen gula di dunia. Menurut data Departemen Pertanian (2008), terdapat 380 ribu Ha areal tanaman tebu sebagai bahan baku gula putih dan 4 pabrik gula rafinasi berbahan baku gula mentah impor di Indonesia. Meskipun berstatus sebagai produsen gula, industri gula dalam negeri masih belum mampu memenuhi kebutuhan dalam negerinya sendiri. Kebutuhan gula nasional dari waktu ke waktu mengalami peningkatan. Kondisi swasembada gula diupayakan melalui pengembangan gula tebu dan juga 
melalui sumber bahan baku lain, salah satunya adalah dari tanaman aren. Jawa Barat memiliki areal panen aren seluas 14.204 Ha dengan produksi 22.489 ton dan produktivitas mencapai $2.781 \mathrm{~kg} / \mathrm{Ha}$ (Dinas Perkebunan Provinsi Jawa Barat 2015).

Keunggulan gula aren adalah proses larutnya ke dalam cairan tubuh berlangsung dalam waktu yang lama, sehingga gula aren mampu memberikan energi dalam rentang waktu yang lebih panjang. Selain itu, riboflavin yang di kandungnya dapat melancarkan metabolisme dan memperbaiki sel sehingga membuat stamina tetap prima (Kartika et al. 2013). Gula aren sangat berpotensi dalam mendukung penyediaan bahan baku industri gula. Potensi aren yang cukup besar merupakan potensi ekonomi yang dapat memberikan konstribusi dalam pembangunan melalui upaya pemberdayaan masyarakat di pedesaan. Daerah Pasir Mukti di desa Tenjowaringin merupakan salah satu daerah penghasil aren di Kabupaten Tasikmalaya Provinsi Jawa Barat. Masyarakat di daerah ini biasa mengolah nira menjadi gula aren di rumahnya masing-masing.

Nira aren berasal dari lengan bunga jantan sebagai bahan untuk produksi gula aren. Mutu nira sangat menentukan mutu gula aren. Nira yang berkualitas tinggi akan menjadi kunci usaha gula aren. Nira aren cepat mengalami perubahan menjadi asam karena terjadinya proses fermentasi, yang biasanya diakibatkan karena terlambatnya perlakuan pengolahan setelah penyadapan, ataupun karena tidak bersihnya alat penampung nira tersebut.

Gula aren yang bermutu bagus dihasilkan dari nira yang bagus atau tidak rusak. Banyak penelitian sudah dilakukan untuk memperpanjang umur simpan nira, baik nira tebu, nira kelapa, maupun nira aren, salah satu caranya adalah dengan menambahkan pengawet alami. Masyarakat Pasir Mukti dulunya biasa menggunakan pengawet alami untuk mempertahankan mutu nira, yaitu daun tanaman hiris (Cajanus cajan) yang ditumbuk atau dihaluskan lalu dimasukkan ke dalam nira aren. Selain itu masyarakat juga biasanya menambahkan gula yang sudah masak ke dalam nira. Naufalin et al. (2013) membuktikan bahwa penambahan bubuk kulit manggis dengan konsentrasi $4.5 \%$ efektif menghambat kerusakan nira kelapa dibandingkan dengan daun jambu biji dan daun cengkeh pada konsentrasi yang sama. 
Penelitian ini bertujuan untuk mengamati pengaruh pemberian pengawet alami berupa bubuk daun hiris, bubuk kulit manggis, dan gula aren dalam dalam meningkatkan kualitas nira aren yang dilakukan dalam beberapa konsentrasi (b/v).

Kegiatan ini dilakukan untuk meneliti pengaruh pemberian beberapa pengawet alami (bubuk kulit manggis, daun tanaman hiris, dan gula merah) terhadap kualitas nira aren sehingga menghasilkan gula aren yang bagus. Penelitian ini dilaksanakan di Desa Tenjowaringin yang berada di Kecamatan Salawu Kabupaten Tasikmalaya. Hasil dari penelitian ini nantinya diharapkan memberikan informasi yang objektif bagi masyarakat penghasil gula aren agar bisa meningkatkan produksi dan mutu gula aren dengan umur simpan nira yang lebih panjang setelah menggunakan pengawet alami tanpa menurunkan nilai gizinya. Menurut Lasut (2012), nira aren dihasilkan dari penyadapan tandan bunga, baik bunga jantan maupun bunga betina. Akan tetapi biasanya tandan bunga jantan dapat menghasilkan nira dengan kualitas yang lebih baik dan jumlah yang lebih banyak dibandingkan tandan bunga betina. Menurut Fatriani et al. (2012), biasanya penyadapan nira hanya dilakukan pada tandan bunga jantan. Nira yang dihasilkan dari tangkai bunga jantan aren lalu ditampung dalam bumbung (batang bambu yang panjangnya antara 1-1,5 meter).

Penyadapan nira dilakukan 2 kali sehari, yaitu pagi dan sore. Setiap tandan bunga jantan dapat disadap selama 2-4 bulan sampai tandan mengering. Hasil dari air aren dapat diolah menjadi gula aren, tuak, cuka dan minuman segar (Lasut 2012). Komponen kimia yang terdapat dalam nira diantaranya adalah protein, mineral dan vitamin. Kandungan protein dalam nira berhubungan dengan metabolisme enzimatis gula (Pontoh et al. 2011). Nira memiliki sifat mudah rusak sehingga perlu adanya penanganan khusus agar tetap segar dan bisa dinikmati oleh semua orang, baik dalam bentuk minuman, pembuatan gula, pembuatan alkohol, dan lain-lain,sehingga dapat meningkatkan nilai jual nira itu sendiri (Jaya 2015). Nira aren dapat mengalami fermentasi karena memiliki kandungan gula yang cukup tinggi dan kehadiran mikroba di dalamnya. Menurut kebiasaan masyarakat, penggunaan nira yang baik yaitu beberapa saat setelah disadap dan tidak boleh dibiarkan bermalam, karena akan mengubah cita rasa menjadi asam 
(Mussa 2014). Pada proses fermentasi nira kandungan gula akan menurun dengan cepat (Jaya et al. 2016).

Gula aren memiliki nilai gizi yang lebih baik dibandingkan gula tebu, karena mengandung vitamin dan mineral yang tidak terdapat pada gula tebu. Gula aren memiliki kadar air $4.11 \%$, lemak $0.11 \%$, serat $0.02 \%$, dan gula reduksi 9.31\%. $\mathrm{pH}$ gula aren adalah 5.5, memiliki $0.09 \%$ total asam tertitrasi, $\mathrm{a}_{\mathrm{w}} 0.5$, dan vitamin C $1.76 \mathrm{mg} / 100 \mathrm{~g}$ (Choong et al. 2016). Secara tradisional, masyarakat mengolah nira aren menjadi gula batu (gula merah) atau gula semut yang berupa kristal (Baharuddin et al. 2007). Salah satu tahap penting dalam pembuatan gula aren tersebut adalah pemanasan untuk menguapkan airnya sehingga gula menjadi terkonsentrasi. Pada pembuatan gula tradisional, hal ini dilakukan dengan cara sederhana yaitu dengan cara memanaskan nira hingga mendidih. Pendidihan akan menyebabkan air menguap ke udara sehingga akan terbentuk larutan sirup kental (Effendi 2010).

Kulit buah manggis mengandung alkaloid, saponin, triterpenoid, tanin, fenolik, flavonoid, glikosida dan steroid. Saponin, tanin dan flavonoid, merupakan senyawa pada tumbuhan yang mempunyai aktivitas antibakteri. Saponin merupakan zat aktif yang dapat meningkatkan permeabilitas membran sehingga terjadi hemolisis sel, apabila saponin berinteraksi dengan sel kuman, kumantersebut akan pecah atau lisis. Flavonoid merupakan kelompok senyawa fenol yang mempunyai kecenderungan untuk mengikat protein, sehingga mengganggu proses metabolisme. Tanin dalam konsentrasi rendah mampu menghambat pertumbuhan kuman. Kulit buah manggis memiliki beberapa khasiat diantaranya adalah sebagai anti mikroba, memperkuat sistem kekebalan tubuh, sebagai antioksidan, dan menghambat pertumbuhan bakteri dan jamur, menurunkan berat badan (Rismunandar, 1986).

Pengawet dari ekstrak kulit buah manggis menunjukkan total gula yang lebih tinggi dibandingkan pengawet dari daun teh dan daun jambu biji, hal ini disebabkan kulit manggis mengandung senyawa anti mikroba yang tinggi sehingga tidak terjadi kerusakan gula di dalam nira aren (Soritua, 2015). Di Afrika, daun tanaman hiris dikonsumsi sebagai sayuran. Nix et al. (2015) 
melaporkan bahwa pada daun Cajanus cajan terdapat flavonoid seperti apigenin, biochanin A, cajanol, formonentin, isorhamnetin, luteolin, orientin, pinostrobin, quersetin, dan vitexin. Parubak (2013) melaporkan bahwa alkaloid, flavonoid, tanin, saponin yang terkandung dalam daun akway (Drimys beccariana, Gibbs) berpotensi sebagai antibakteri.

\section{METODE PENELITIAN}

\section{Waktu dan Tempat}

Penelitian dilaksankan di Laboratorium Terpadu Fakultas Pertanian Universitas Garut DAN Laboratorium Fakultas Teknik Universitas Pasundan Bandung. Penelitian dilakukan selama tiga bulan dari bulan Mei 2018 sampai bulan Agustus 2018.

\section{Materi Penelitian}

Bahan baku yang digunakan adalah nira aren, daun hiris yang berasal dari Pasir Mukti, Desa Tenjowaringin, Kecamatan Salawu, Kabupaten Tasikmalaya, Provinsi Jawa Barat. Bubuk kulit manggis diperoleh dari Desa Puspahiang, Kecamatan Taraju, Kabupaten Tasikmalaya, Provinsi Jawa Barat. Bahan kimia yang diguanakan adalah: aquades, glukosa anhidrat, dan reagen luff. Alat yang digunakan adalah hand $\mathrm{pH}$ meter, refraktometer, erlenmeyer, oven, tanur, kabinet dryer, spektrofotometer UV.

\section{Prosedur Penelitian}

\section{Pembuatan Pengawet Alami}

Bahan pengawet alami (kulit manggis dan daun tanaman hiris) dikeringkan menggunakan kabinet dryer pada suhu $50^{\circ} \mathrm{C}$ selama 20 jam, kemudian dihaluskan menjadi bubuk dan diayak menggunakan saringan 60 mesh. Bubuk pengawet alami (termasuk bubuk gula merah) dilarutkan dalam aquades dengan konsentrasi $3 \%, 4.5 \%$, dan $6 \%$.

\section{Penambahan Pengawet Alami pada Nira Aren}


Pemberian pengawet dilakukan pada nira aren dengan $\mathrm{pH}$ netral (6.5). Konsentrasi pengawet alami yang ditambahkan sebesar 3\%, 4.5\%, dan 6\% (b/v), yaitu $3 \mathrm{~g}, 4.5 \mathrm{~g}$, dan $6 \mathrm{~g}$ dalam $100 \mathrm{ml}$ nira aren. Nira hasil penyadapan dicampur secara homogen dan dituang ke dalam wadah.

\section{Pembuatan Gula Aren}

Pembuatan gula aren dibuat dari nira aren yang ditambahkan pengawet alami. Nira hasil penyadapan dipanaskan di atas tungku pada suhu $115-117{ }^{\circ} \mathrm{C}$. Pemanasan disertai dengan pengadukan dan dilanjutkan sampai terbentuk solidifikasi, kemudian dicetak dan dihasilkan gula aren.

\section{Metode Penelitian}

Metode penelitian yang digunakan menggunakan metode eksperimental. Rancangan percobaan yang digunakan adalah Rancangan Acak Lengkap 2 faktor (RAL faktorial). Faktor I adalah 3 taraf jenis pengawet alami (bubuk kulit manggis, daun tanaman hiris, dan gula merah), sedangkan faktor II adalah 3 taraf konsentrasi pengawet $(3 \%, 4.5 \%$, dan $6 \%)$, dan tiap perlakuan diulang 3 kali sehingga diperoleh 27 unit percobaan.

\section{Analisis Statistik}

Data yang diperoleh dianalisis ragam (uji F) pada taraf 5\% dan apabila menunjukkan adanya keragaman maka dilanjutkan dengan uji Duncan's Multiple Range Test (DMRT).

\section{Variabel}

Variabel yang diamati adalah sebagai berikut:

1. Analisis kadar gula pereduksi.

Timbang lebih kurang 5 gr sampel. Larutkan dengnan aquades dalam labu ukur $250 \mathrm{ml}$ sampai tanda batas. Kemudian pipet larutan ini sebanyak $25 \mathrm{ml}$ dan tambahkan $25 \mathrm{ml}$ reagen Luff, lalu panaskan selama 10 menit mendidih dengan pendingin tegak. Setelah dingin tambahkan $25 \mathrm{ml} \mathrm{H} 2 \mathrm{SO} 4$ 24\%, KI $20 \%$ sebanyak 
$25 \mathrm{ml}$. Titrasi dengan larutan Thio $0,1 \mathrm{~N}$ dengan memakai indikator amilum 0,5

$\%$. Buat penitran blanko yaitu $25 \mathrm{ml}$ aquades dengan $25 \mathrm{ml}$ reagen luff.

$$
\text { kadar gula }=\frac{\text { mg sakarida } \mathrm{xfp} \times 100 \%}{m g \text { sampel }}
$$

2. Analisis kadar air dengan metode oven, mengacu pada AOAC (1995). Kadar air diukur dengan metode oven biasa karena kandungan bahan volatil pada sampel rendah dan sampel tidak terdegradasi pada suhu $100^{\circ} \mathrm{C}$. Cawan aluminium kosong dikeringkan dalam oven bersuhu $105^{\circ} \mathrm{C}$ selama 15 menit lalu didinginkan dalam desikator selama 5 menit atau sampai tidak panas lagi. Cawan ditimbang dan dicatat beratnya. Lalu ditimbang sampel sebanyak $5 \mathrm{~g}$ di dalam cawan tersebut. Sampel dikeringkan dalam oven sampai beratnya konstan (perubahan berat tidak lebih dari $0,003 \mathrm{~g}$ ). Setelah itu cawan didinginkan di dalam desikator lalu ditimbang berat akhirnya.

Dihitung kadar air dengan persamaan sebagai berikut:

$$
\text { kadar air }(\% \mathrm{~b} / \mathrm{b})=\frac{(x-y) \times 100 \%}{(x-a)}
$$

Keterangan :

$\mathrm{x}=$ berat cawan dan sampel sebelum dikeringkan $(\mathrm{g})$

$\mathrm{y}=$ berat cawan dan sampel setelah dikeringkan $(\mathrm{g})$

$\mathrm{a}=$ berat cawan kosong $(\mathrm{g})$

\section{Analisis Statistik}

Data yang diperoleh dianalisis ragam (uji $\mathrm{F}$ ) pada taraf 5\% dan apabila menunjukkan adanya keragaman maka dilanjutkan dengan uji Duncan's Multiple Range Test (DMRT).

\section{HASIL DAN PEMBAHASAN}

\section{Pengaruh Perlakuan terhadap Kandungan Gula Pereduksi}

\section{Kandungan Gula Pereduksi}

Pada tahap awal, dilakukan pengambilan sampel bahan yang akan digunakan sebagai bahan penelitian yaitu daun hiris, kulit manggis dan gula aren. Bahan pengawet alami ini di tambahkan kedalam nira sesuai dosisnya, kemudian diolah menjadi gula aren. Setelah menjadi gula aren semua bahan ini di analisis di laboratorium teknik Universitas Pasundan. Dari hasil analisis kandungan gula 
pereduksi yang terdapat pada gula aren yang ditambahkan beberapa pengawet alami diperoleh sebagai berikut.

Gula pereduksi adalah gula yang memiliki gugus aldehid bebas pada struktur kimianya. Kandunga gula pereduksi berperan dalam proses pencoklatan. Gula pereduksi juga mempengaruhi tingakt kemanisan karena glukosa dan fruktosa mempunyai tingkat kemanisan yang lebih rendah.

Pembentukan gula pereduksi ini ada yang disengaja namun ada juga yang dicegah. Pembentukan gula pereduksi disengaja melalui proses inverse untuk menghasilkan gula invert

Tabel. 2 Kandungan Gula Pereduksi pada Gula Aren yang diberikan 3 Pengawet Alami: Daun Hiris, Kulit Manggis dan Gula Aren

\begin{tabular}{|c|c|c|c|c|}
\hline \multirow{2}{*}{$\begin{array}{l}\text { Level pengawet } \\
(\mathrm{cm})\end{array}$} & \multirow[b]{2}{*}{ Ulangan } & \multicolumn{3}{|c|}{ Jenis pengawet } \\
\hline & & GM & DH & $\mathbf{K M}$ \\
\hline \multirow{4}{*}{3} & 1 & 9,2397 & 7,6710 & 5,8314 \\
\hline & 2 & 8,7471 & 6,6788 & 5,5732 \\
\hline & 3 & 7,7162 & 6,2029 & 5,2429 \\
\hline & Rataan & 8,5677 & 6,8509 & 5,5492 \\
\hline \multirow{4}{*}{4,5} & I & 3,7100 & 3,5671 & 4,0142 \\
\hline & 2 & 3,5129 & 3,6287 & 3,9663 \\
\hline & 3 & 3,3446 & 4,0692 & 3,8120 \\
\hline & Rataan & 3,5225 & 3,7550 & 3,9308 \\
\hline \multirow[t]{4}{*}{6} & 1 & 3,8219 & 3,7585 & 4,3139 \\
\hline & 2 & 3,8222 & 3,6553 & 4,3535 \\
\hline & 3 & 3,5960 & 3,1322 & 4,2341 \\
\hline & Rataan & 3,7467 & 3,5153 & 4,3005 \\
\hline Total Rataan & & 5,2789 & 4,7071 & 4,5935 \\
\hline
\end{tabular}

Pada Tabel 2. menunjukkan bahwa kandungan gula pereduksi secara keseluruhan berkisar antara 3,5225 - 8,5677 total rataan berkisar 4,5935 - 5,2789.

Pengaruh perlakuan terhadap kandungan gula pereduksi dapat diketahui dengan melakukan analisis sidik ragam. Hasil analisi sidik ragam menunjukkan bahwa interaksi antara level pengawet dengan jenis pengawet ternyata tidak ditemukan.Namun pemberian dosis pengawet berpengaruh secara nyata terhadap kandungan gula pereduksi, begitupun jenis pengawet berpengaruh terhadap kandungan gula pereduksi.

Kandungan gula pereduksi terendah ada pada jenis pengawet kulit manggis $=4,6 \%$. Kandungan gula pereduksi tertinggi ada pada jenis pengawet gula aren $=5,3 \%$. Hal ini dapat disebabkan oleh ketelitian dalam penanganan nira mulai dari penyadapan di hutan/ kebun sampai di olah di rumah. Gula pereduksi 
dapat mempengaruhi proses pengkristalan gula. Semakin tinggi kandungan gula pereduksi dalam suatu bahan gula maka akan menghambat proses pengkristalan gula [18]. Jika kandungan gula pereduksinya rendah maka akan mempercepat proses pengkristalan gula tersebut.

Tabel. 3 Hasil Uji Jarak Berganda Duncan Pengaruh Pemberian Dosis Pengawet terhadap Kandungan Gula Pereduksi pada Gula Aren

\begin{tabular}{|c|c|c|}
\hline Perlakuan & Rataan (\%) & Signifikansi $(0,05)$ \\
\hline 6 & 3,854 & A \\
\hline 4,5 & 3,7361 & A \\
\hline 3 & 6,989 & $\mathrm{~b}$ \\
\hline
\end{tabular}

Keterangan: huruf kecil yang berbeda kearah baris menunjukkan pengaruh yang berbeda diantara perlakuan

Berdasarkan hasil uji jarak Duncan pada tabel 3 dapat diketahui bahwa kandungan gula pereduksi terendah ada pada dosis 4,5 dengan rataan $3,7361 \%$.

Tabel. 4 Hasil Uji Jarak Berganda Duncan Pengaruh Pemberian Jenis Pengawet terhadap Kandungan Gula Pereduksi pada Gula Aren

\begin{tabular}{|c|c|c|}
\hline Perlakuan & Rataan (\%) & Signifikansi $(0,05)$ \\
\hline $\mathrm{DH}$ & 4,7071 & $\mathrm{~A}$ \\
\hline GM & 5,2789 & $\mathrm{~B}$ \\
\hline KM & 4,5935 & $\mathrm{C}$ \\
\hline
\end{tabular}

Ket: huruf kecil yang berbeda kearah baris menunjukkan pengaruh yang berbeda diantara perlakuan

Berdasarkan hasil uji jarak Duncan pada tabel 4 dapat diketahui bahwa kandungan gula pereduksi terendah ada pada jenis pengawet KM yaitu Kulit Manggis dengan rataan 4,5935\%.

\section{Kandungan Kadar Air}


Kadar air sangat penting untuk mengetahui mutu suatu produk pangan. Air yang terdapat dalam bentuk bebas pada bahan pangan dapat membantu terjadinya proses kerusakan pangan. Kadar air dalam suatu bahan berperan dalam reaksi kimia, perubahan enzimatis ataupun pertumbuhan mikroorganisme. Hal tersebut terjadi umumnya pada kadar air tinggi dan akan dipengaruhi pula oleh faktor lingkungan seperti $\mathrm{pH}$ dan suhu. Kadar air berpengaruh terhadap stabilitas dan kualitas produk secara keseluruhan. Hasil analisis kandungan Kadar Air yang terdapat pada gula aren yang ditambahkan beberapa pengawet alami diperoleh sebagai berikut.

Tabel. 5 Kandungan Kadar Air pada Gula Aren yang diberikan 3 Pengawet Alami: Daun Hiris, Kulit Manggis dan Gula Aren

\begin{tabular}{|c|c|c|c|c|}
\hline \multirow{2}{*}{ Level pengawet $(\mathrm{cm})$} & \multirow{2}{*}{ Ulangan } & \multicolumn{3}{|c|}{ Jeais pengawet } \\
\hline & & GM & DH & KM \\
\hline \multirow{4}{*}{3} & 1 & 0,9653 & 0,9747 & 1,6857 \\
\hline & 2 & 0.6432 & 1,2273 & 1,3158 \\
\hline & 3 & 0,6317 & 0,6247 & 2,0720 \\
\hline & Rataan & 0,7467 & 0,9422 & 1,6911 \\
\hline \multirow{4}{*}{4,5} & 1 & 2,8051 & 2,3879 & 2,3506 \\
\hline & 2 & 2,4126 & 2,8079 & 2,1782 \\
\hline & 3 & 2,2059 & 3.2619 & 1,8278 \\
\hline & Rataan & 2,4745 & 2,8192 & 2,1188 \\
\hline \multirow[t]{4}{*}{6} & 1 & 1,8803 & 2,8972 & 0,9761 \\
\hline & 2 & 1,9024 & 2,9098 & 1,0189 \\
\hline & 3 & 1,1052 & 2,8944 & 0,9602 \\
\hline & Rataan & 1,6293 & 2.9005 & 0,9851 \\
\hline Total Rataan & & 1,6168 & 2,2206 & 1,5983 \\
\hline
\end{tabular}

Tabel 5 menunjukkan bahwa kandungan kadar air secara keseluruhan berkisar antara 0,7467 - 2,8192. Total rataan berkisar 1,5983 - 2,2206. Pengaruh perlakuan terhadap kandungan kadar air dapat diketahui dengan melakukan analisis sidik ragam.

Hasil analisis menunjukkan bahwa terdapat interaksi antara level pengawet dengan jenis pengawet. Secara mandiri pemberian dosis pengawet pun berpengaruh secara nyata terhadap kandungan kadar air, begitupun jenis pengawet berpengaruh terhadap kandungan kadar air.

Kandungan kadar air terendah ada pada jenis pengawet Kulit Manggis = 1,5983. Kandungan kadar air tertinggi ada pada jenis pengawet Gula Aren = 
2,2206. Hal ini dapat disebabkan oleh ketelitian dalam penanganan nira mulai dari proses penyadapan di hutan/ kebun sampai di olah di rumah.

Tabel. 6 Hasil Uji Jarak Berganda Duncan Pengaruh Pemberian Dosis Pengawet terhadap Kandungan Kadar Air pada Gula Aren

\begin{tabular}{|c|c|c|}
\hline Perlakuan & Rataan $(\%)$ & Signifikansi $(0,05)$ \\
\hline 6 & 1,8382 & A \\
\hline 4,5 & 2.4708 & B \\
\hline 3 & 1.1267 & $\mathrm{C}$ \\
\hline
\end{tabular}

Ket: huruf kecil yang berbeda kearah baris menunjukkan pengaruh yang berbeda diantara perlakuan

Berdasarkan hasil uji jarak berganda Duncan pada tabel 6 dapat diketahui bahwa kandungan kadar air terendah ada pada pemberian dosis 3 dengan rataan 1,1267\%.

Tabel. 7 Hasil Uji Jarak Berganda Duncan Pengaruh Pemberian Jenis Pengawet terhadap Kandungan Kadar Air pada Gula Aren

\begin{tabular}{|c|c|c|}
\hline Perlakuan & Rataan (\%) & Signifikansi $(0,05)$ \\
\hline $\mathrm{DH}$ & 2,2206 & $\mathrm{~A}$ \\
\hline GM & 1,6168 & B \\
\hline KM & 1,5983 & $\mathrm{C}$ \\
\hline
\end{tabular}

Ket: Huruf kecil yang berbeda kearah baris menunjukkan pengaruh yang berbeda nyata diantara perlakuan

Berdasarkan hasil uji jarak berganda Duncan pada tabel 7 dapat diketahui bahwa kandungan kadar air terendah ada pada pemberian jenis pengawet KM yaitu Kulit Manggis dengan rataan $1,5983 \%$.

\section{Kandungan Gula Invert}

Gula invert yang banyak mengandung gula pereduksi akan lebih mudah mengalami proses pencoklatan sehingga warnanya lebih coklat. Hasil analisis 
kandungan Kandungan Gula Invert yang terdapat pada gula aren yang ditambahkan beberapa pengawet alami diperoleh sebagai berikut.

Tabel 8. Pengaruh perlakuan terhadap kandungan gula invert gula aren

\begin{tabular}{|c|c|c|c|c|}
\hline \multirow{2}{*}{$\begin{array}{c}\text { Level } \\
\text { pengawet } \\
(\mathrm{cm})\end{array}$} & \multirow[b]{2}{*}{ Ulangan } & \multicolumn{3}{|c|}{ Jenis pengawet } \\
\hline & & GM & $\mathrm{DH}$ & $\mathrm{KM}$ \\
\hline \multirow{4}{*}{3} & 1 & 47.1906 & 33.8425 & 49.3427 \\
\hline & 2 & 42,6141 & 93.3942 & 42.3564 \\
\hline & 3 & 42.8676 & 34.2613 & 41.9429 \\
\hline & Rataan & 44.2241 & 33.83267 & 44.54733 \\
\hline \multirow{4}{*}{4,5} & 1 & 40.3266 & 24.3214 & 35.6814 \\
\hline & 2 & 38.3230 & 27.6474 & 39.6627 \\
\hline & 3 & 38.2242 & 27.8422 & 40.1267 \\
\hline & Rataan & 38.95793 & 26.60367 & 38.49027 \\
\hline \multirow[t]{4}{*}{6} & 1 & 38.2192 & 32.8873 & 45,4096 \\
\hline & 2 & 38.2221 & 33.1260 & 45.8267 \\
\hline & 3 & 38.0752 & 39.4097 & 44.5696 \\
\hline & Rataan & 38.17217 & 33.141 & 45.26863 \\
\hline Total Rataan & & 40.4514 & 31.1924 & 42,7687 \\
\hline
\end{tabular}

Tabel 8 menunjukkan bahwa kandungan gula invert secara keseluruhan berkisar antara 33, $1924-45,2686$ total raataan berkisar 31,1924 - 42, 7687. Pengaruh perlakuan terhadap kandungan gula invert dapat diketahui dengan melakukan anaisis sidik ragam. Hasil analisis menunjukkan bahwa interaksi antara level pengawet dengan jenis pengawet ternyata tidak ditemukan. Namun dosis pemberian pengawet berpengaruh secara nyata terhadap kandungan gula invert, begitupun jenis pengawet berpengaruh terhadap kandungan gula invert.

Kandungan gula pereduksi terendah ada pada jenis pengawet kulit manggis $=26,6 \%$ dengan level pengawet 4,5 . Sedangkan kandungan gula invert tertinggi ada pada jenis pengawet gula kulit manggis $=44,55 \%$ dengan level pengawet 3. Gula invert dihasilkan dari hidrolisis sukrosa baik secara enzimatik maupun secara kimia dengan katalis asam bebas. Hidrolisis sukrosa secara enzimatik menghasilkan gula invert yang jernih dan bermutu tinggi. Nilai invert yang tinggi menyebabkan tidak dapatnya berbentuk kristal karena kelarutan fruktosa yang sangat besar. Maka kadar invert terbaik dalam peneltian ini dengan menggunakan pengawet alami kulit manggis level pengawet 4,5 dengan kadar 
nilai invert terendah. Hal ini terlihat dengan lebih mudahnya mengkristal nira pada proses pengolahan gula aren.

Tabel 9. Hasil Uji jarak berganda Duncan pengaruh pemberian dosis pengawet terhadap kandungan gula invert gula aren

\begin{tabular}{llc}
\hline Perlakuan & Rataan $(\%)$ & Signifikansi $(0,05)$ \\
\hline 4.5 & 34,683 & A \\
6 & 38,860 & B \\
3 & 40,868 & C
\end{tabular}

Keterangan : huruf kecil yang berbeda kearah baris menunjukan pengaruh yang berbeda diantara perlakuan.

Berdasarkan hasil uji jarak berganda Duncan pad atabel 9 dapat diketahui bahwa kandungan gula invert terendah pada perlakuan dengan dosis pengawet 4,5 .

Tabel 10. Hasil Uji jarak berganda Duncan pengaruh pemberian dosis pengawet terhadao kandungan gula invert gula aren

\begin{tabular}{lcc}
\hline Perlakuan & Rataan $(\%)$ & Signifikansi $(0,05)$ \\
\hline DH & 31,192 & A \\
GM & 40,451 & B \\
KM & 42,768 & C \\
\hline
\end{tabular}

Keterangan : huruf kecil yang berbeda kearah baris menunjukan pengaruh yang berbeda diantara perlakuan.

\section{Kandungan Gula Total}

Hasil analisis kandungan kandungan gula total yang terdapat pada gula aren yang ditambahkan beberapa pengawet alami diperoleh sebagai berikut.

Tabel 11. Pengaruh perlakuan terhadap kandungan gula total gula aren 


\begin{tabular}{|c|c|c|c|c|}
\hline \multirow{2}{*}{$\begin{array}{c}\text { Level } \\
\text { pengawet } \\
(\mathrm{cm})\end{array}$} & \multirow{2}{*}{ Ulangan } & \multicolumn{3}{|c|}{ Jenis pengawet } \\
\hline & & GM & $\mathrm{DH}$ & $\mathrm{KM}$ \\
\hline \multirow{4}{*}{3} & 1 & 9.26 & 9.76 & 9.86 \\
\hline & 2 & 9.36 & 9.96 & 10.06 \\
\hline & 3 & 9.56 & 10.16 & 10.36 \\
\hline & Rataan & 9.39 & 9.96 & 10.09 \\
\hline \multirow{4}{*}{4,5} & 1 & 9.36 & 9.76 & 9.86 \\
\hline & 2 & 9.76 & 9.56 & 9.76 \\
\hline & 3 & 10.16 & 9.56 & 9.96 \\
\hline & Rataan & 9.76 & 9.63 & 9.86 \\
\hline \multirow[t]{4}{*}{6} & 1 & 9.36 & 9.76 & 9.66 \\
\hline & 2 & 9.76 & 9.86 & 9.76 \\
\hline & 3 & 10.16 & 10.06 & 9.96 \\
\hline & Rataan & 9.76 & 9.89 & 9.79 \\
\hline Total Rataan & & 9.64 & 9.83 & 9.91 \\
\hline
\end{tabular}

Tabel 11 menunjukkan bahwa kandungan gula total secara keseluruhan berkisar antara 9,63 - 10,09 total raataan berkisar 9,64 - 9,91. Pengaruh perlakuan terhadap kandungan gula total dapat diketahui dengan melakukan anaisis sidik ragam. Hasil analisis menunjukkan bahwa level pemberian dan jenis pengawet serta interaksi antara level pengawet dengan jenis pengawet ternyata tidak ditemukan.

Tabel 12. Hasil Uji jarak berganda Duncan pengaruh pemberian dosis pengawet terhadap kandungan gula total gula aren

\begin{tabular}{llc}
\hline Perlakuan & Rataan $(\%)$ & Signifikansi $(0,05)$ \\
\hline 4.5 & 9,75 & A \\
6 & 7,559 & b \\
3 & 9,813 & C
\end{tabular}

Keterangan : huruf kecil yang berbeda kearah baris menunjukan pengaruh yang berbeda diantara perlakuan. 
Berdasarkan hasil uji jarak berganda Duncan pada tabel 12 dapat diketahui bahwa kandungan gula total terendah pada perlakuan level pengawet 6 dengan rataan 7,559 .

Tabel 13. Hasil Uji jarak berganda Duncan pengaruh pemberian dosis pengawet terhadap kandungan gula total gula aren

\begin{tabular}{llc}
\hline Perlakuan & Rataan $(\%)$ & Signifikansi $(0,05)$ \\
\hline DH & 9,826 & A \\
GM & 9,636 & B \\
KM & 9,913 & C \\
\hline
\end{tabular}

Keterangan : huruf kecil yang berbeda kearah baris menunjukan pengaruh yang berbeda diantara perlakuan.

Berdasarkan uji Duncan untuk pengaruh jenis pengawet alami yang paling tinggi kandungan gula totalnya adalah pada kulit manggis yaitu 9,913.

\section{Kadar Abu}

Kadar abu termasuk salah satu penentu mutu gula, kadar abu yang tinggi menurunkan mutu gula. Hasil analisis kadar abu yang terdapat pada gula aren yang ditambahkan beberapa pengawet alami diperoleh sebagai berikut. Kadar abu maksimal pada gula aren menurut standar SNI adalah 2.

Tabel 14. Pengaruh perlakuan terhadap kandungan kadar abu gula aren 
Tabel 14. Menunjukkan bahwa kandungan abu total secara keseluruhan berkisar antara $1,0986-1,7617$ total raataan berkisar $1,5057-1,5553$

Tabel 14. Pengaruh perlakuan terhadap kandungan kadar abu gula aren

\begin{tabular}{|c|c|c|c|c|}
\hline \multirow{2}{*}{$\begin{array}{c}\text { Level } \\
\text { pengawet } \\
(\mathrm{cm})\end{array}$} & \multirow[b]{2}{*}{ Ulangan } & \multicolumn{3}{|c|}{ Jenis pengawet } \\
\hline & & GM & $\mathrm{DH}$ & $\mathrm{KM}$ \\
\hline & 1 & 1.763 & 1.3436 & 1.5984 \\
\hline \multirow[t]{3}{*}{3} & 2 & 1.7258 & 1.7017 & 1.497 \\
\hline & 3 & 1.7964 & 1.7964 & 1.5984 \\
\hline & Rataan & 1.761733 & 1.6139 & 1.5646 \\
\hline \multirow{4}{*}{4} & 1 & 1.7383 & 1.5398 & 1.5052 \\
\hline & 2 & 1.6775 & 1.4164 & 1.4774 \\
\hline & 3 & 1.5549 & 1.4299 & 1.619 \\
\hline & Rataan & 1.6569 & 1.462033 & 1.533867 \\
\hline \multirow[t]{4}{*}{6} & 1 & 1.023 & 1.4774 & 1.6457 \\
\hline & 2 & 1.1439 & 1.7143 & 1.5539 \\
\hline & 3 & 1.1289 & 1.5785 & 1.3724 \\
\hline & Rataan & 1.0986 & 1.590067 & 1.524 \\
\hline Total Rataan & & 1.5057 & 1.5553 & 1.5408 \\
\hline
\end{tabular}

Pengaruh perlakuan terhadap kandungan gula total dapat diketahui dengan melakukan anaisis sidik ragam. Hasil analisis menunjukkan bahwa terdapat interaksi antara level pengawet dengan jenis pengawet. Secara mandiri level pengawet berpengaruh nyata terhadap kadar abu, namun jenis pengawet memberikan hasil yang tidak berpengaruh nyata namun sudah memenuhi syarat SII maksimum $2 \%$. 
Tabel 15. Hasil Uji jarak berganda Duncan pengaruh pemberian dosis pengawet terhadap kandungan abu gula aren

\begin{tabular}{lcc}
\hline Perlakuan & Rataan $(\%)$ & Signifikansi $(0,05)$ \\
\hline 6 & 1,4042 & A \\
4,5 & 1,5509 & B \\
3 & 1,6467 & C \\
\hline
\end{tabular}

Keterangan : huruf kecil yang berbeda kearah baris menunjukan pengaruh yang berbeda diantara perlakuan.

Berdasarkan hasil uji jarak berganda Duncan pada tabel 15 dapat diketahui bahwa kandungan kadar abu terendah ada pada perlakuan dengan level pengawet 6 yaitu 1.4042

Tabel 16. Hasil Uji jarak berganda Duncan pengaruh pemberian dosis pengawet terhadap kandungan kadar abu gula aren

\begin{tabular}{lcc}
\hline Perlakuan & Rataan $(\%)$ & Signifikansi $(0,05)$ \\
\hline DH & 1.5533 & A \\
GM & 1,5057 & B \\
KM & 1,5408 & C
\end{tabular}

Keterangan : huruf kecil yang berbeda kearah baris menunjukan pengaruh yang berbeda diantara perlakuan.

Berdasarkan hasil uji jarak berganda Duncan pada tabel 16 dapat diketahui bahwa kandungan kadar abu terendah ada pada perlakuan dengan jenis pengawet gula merah yaitu 1.5057

\section{Umur simpan}

Dari 3 jenis pengawet yang digunakan pada penelitian ini, maka pengawet alami yang memiliki umur simpan lebih panjang pada nira aren sebelum diolah menjadi gula aren adalah yang menggunakan daun hiris yaitu 8 jam. Sedangkan yang lebih cepat rusak adalah yang menggunakan gula merah. 


\section{Tingkat Penerimaan Masyarakat}

Gula aren yang diolah, sebelumnya diberikan perlakuan pada nira aren dengan 3 jenis pengawet alami yaitu daun hiris, kulit manggis dan gula merah, dan dosis yang berbeda. Dari hasil survey tingkat kesukaan masyarakat pada gula aren yang sudah diberikan perlakuan menunjukkan perlakuan dengan penambahan gula aren pada nira mampu memiliki rasa yang jauh lebih di sukai daripada dengan menggunakan pengawet alami lainnya.

\section{UCAPAN TERIMAKASIH}

Terima kasih ditujukan kepada Kemenristekdikti atas Hibah Penelitian Dosen Pemula Kementerian Riset, Teknologi, dan Pendidikan Tinggi tahun 2018, dengan Kontrak Penelitian Nomor: 211/R/UNIGA/V/2018 Tanggal 12 Februari 2018.

\section{DAFTAR PUSTAKA}

Naufalin R, Yanto T, Sulistyaningrum A. 2013. Pengaruh jenis dan konsentrasi pengawet alami terhadap mutu gula kelapa. Jurnal Teknologi Pertanian: 14 (3). Hal: $165-174$

Dinas Perkebunan Provinsi Jawa Barat. 2015. Luas dan Produksi Tanaman Perkebunan di Jawa Barat. Tersedia pada http://disbun.jabarprov.go.id/index.php/statistik/. Diakses pada 20 April 2017

Kartika D, Aristarchus PK, Margana. 2013. Perancangan buku esai fotografi pembuatan gula aren.

Naufalin R, Yanto T, Sulistyaningrum A. 2013. Pengaruh jenis dan konsentrasi pengawet alami terhadap mutu gula kelapa. Jurnal Teknologi Pertanian: 14 (3). Hal: $165-174$

Lasut MT. 2012. Budidaya yang baik aren (Arenga pinnata (Wurmb) Merr.)). Kerjasama Fakultas Pertanian Universitas Sam Ratulangi dan Universitas Texas A \& M. 
Fatriani, Sunardi, Prayudi F. 2012. Pengaruh umur pohon aren (Arenga pinnata merr ) terhadap produksi nira di Desa Pulantan Kecamatan Awayan Kabupaten Balangan Provinsi Kalimantan Selatan. Jurnal Hutan Tropis: 13 (1).

Pontoh J, Gunawan I, Fatimah F. 2011. Analisa kandungan protein dalam nira aren. Chem. Prog: 4(2).

Jaya RS, Ginting S, Ridwansyah. 2015. Pengaruh suhu pemanasan dan lama penyimpanan terhadap perubahan kualitas nira aren (Arenga pinnata). J.Rekayasa Pangan dan Pertanian: 4 (1)

Mussa R. 2014. Kajian tentang lama fermentasi nira aren (Arenga Pinnata) terhadap kelimpahan mikroba dan kualitas organoleptik tuak. Biopendix: 1 (1)

Jaya RS, Ginting S, Ridwansyah. 2015. Pengaruh suhu pemanasan dan lama penyimpanan terhadap perubahan kualitas nira aren (Arenga pinnata). J.Rekayasa Pangan dan Pertanian: 4 (1)

Choong CC, Anzian A, Che Wan Sapawi CWNS, Meor Hussein AS. 2016. Characterization of sugar from Arenga pinnata and Saccharum officinarum sugars. International Food Research Journal 23(4): 1642-1652

Effendi DS. 2010. Prospek pengembangan tanaman aren (Arenga pinnata merr.) mendukung kebutuhan bioetanol di Indonesia. Perspektif Vol. 9 No. 1. Hal $36-46$

Soritua P, Ginting S, Rusmarilin H. 2015. Pengaruh penambahan berbagai bahan pengawet alami dan konsentrasinya terhadap mutu nira aren. J.Rekayasa Pangan dan Pert., Vol.3 No.4

Nix A, Paull CA, Colgrave M. 2015. The flavonoid profile of pigeonpea, Cajanus cajan: a review. SpringerPlus (2015) 4:125. Doi 10.1186/s40064-015-0906$\mathrm{x}$

Parubak AS. 2013. Senyawa flavonoid yang bersifat antibakteri dari akway (Drimys becariana.Gibbs). Chem. Prog. Vol. 6. No.1

Khaerina. 2013. Pembuatan Gula Merah Cetak, Gula Semut, Gula Invert, Dan Produk Hidrolisasi Pati, Serta Analisis Mutu Produk Gula. Laporan 
Praktikum Teknologi Pati Gula dan Sukrokimia, Departemen Teknologi Industri Pertanian Fakultas Teknologi Pertanian Institut Pertanian Bogor.

Rumaya, H., J. Pontoh dan L. Kowel. 2011. Kristalisasi sukrosa pada pembuatan gula kristal dari nira aren. Buletin Palma 12 (2): 100-114. Pusat Penelitian dan Pengembangan Perkebunan. Bogor. 